\title{
Development of Extended Unimpaired Streamflow Records in the Saluda Basin, South Carolina
}

\author{
C. Alex Pellett ${ }^{1}$, John Boyer ${ }^{2}$, Nina Caraway ${ }^{2}$, Tim Cox $^{2}$, Joseph A. Gellici ${ }^{1}$, \\ Scott Harder ${ }^{1}$, Andy Wachob ${ }^{1}$, Kirk Westphal ${ }^{2}$
}

AUTHORS: ${ }^{1}$ South Carolina Department of Natural Resources Hydrology Section, 311 Natural Resources Drive, Clemson, SC 29631, USA. ${ }^{2}$ CDM Smith, 5400 Glenwood Avenue Suite 400, Raleigh, NC 27612, USA.

\begin{abstract}
This paper presents the steps involved and the methodologies employed in the first phase of the South Carolina Surface Water Assessment - development of extended and unimpaired streamflow estimates based on USGS gage data in the Saluda basin. Streamflow data are first adjusted to remove effects of anthropogenic impairments. Adjustments are made for reservoirs, withdrawals, and discharges based on available documentation. Where documentation is insufficient, hindcasting methods are used. The resulting datasets are called unimpaired flows (UIFs).

The UIFs are then extended in time from 1925, the starting date of the first continuous stream discharge data available in the basin, through 2013. Candidate reference gages for each short-record gage are selected based on a qualitative assessment. Area ratio and Maintenance of Variance Extension (Hirsch, 1982) methods are applied. Statistical and graphical evaluation of the extension results is followed by composition of extended UIFs.
\end{abstract}

\section{INTRODUCTION}

Reliable supplies of water are crucial to the quality of life, protection of natural resources, and the continuing prosperity of South Carolina. Although the State presently has adequate water supplies, it is a limited resource that will be increasingly exploited as the State's population increases. Competition for water, intensified by droughts, could lead to water shortages, over-allocation, environmental degradation, or other problems if the resource is not properly managed.

The S.C. Department of Natural Resources (DNR) and the S.C. Department of Health and Environmental Control (DHEC) are currently in the process of assessing surfacewater availability in the State and developing surfacewater quantity models for each of the State's eight major regulatory river basins (Figure 1). The computer simulation models will be used by DNR and DHEC as decisionsupport tools for surface water permitting programs and regional water planning efforts.
The Saluda River basin is the pilot basin for this statewide modeling effort, and the study area for this report. Models will use data from monitoring networks to estimate the volume of surface water that has been available in each basin over the past $70-80$ years.

\section{PURPOSE}

The U.S. Geological Survey (USGS) has maintained streamflow gages in the Saluda River basin in South Carolina since 1925. Natural stream flows have been impaired by a variety of human activities, including withdrawals, discharges, and impoundments. Impairment in this context refers to changes or alterations to the natural flow regime caused by human activities. To the extent that those activities have been recorded or can be estimated, it is possible to remove impairments from streamflow records, producing unimpaired flows (UIFs).

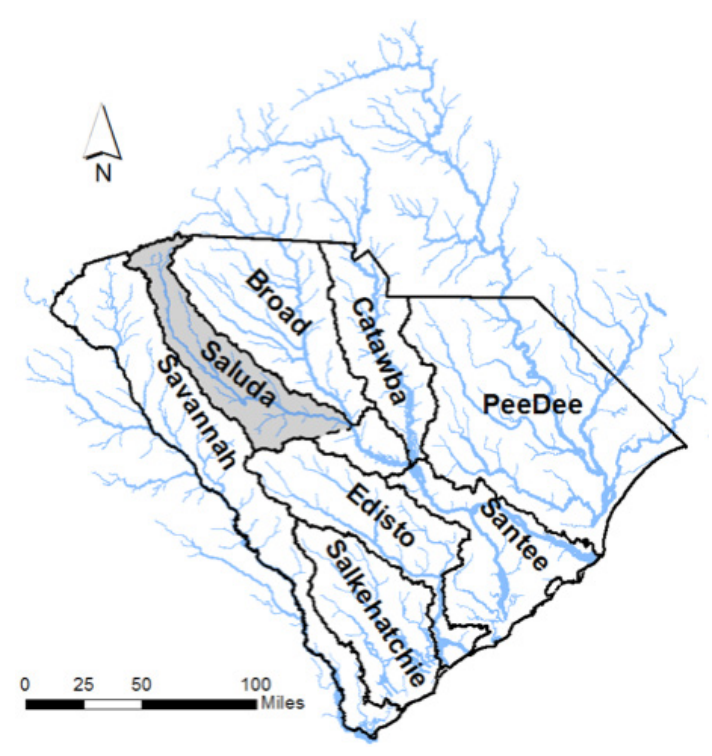

Figure 1. Major rivers and regulatory basins of South Carolina. The portion of the Saluda basin included in this study is shaded. 
UIFs are estimated to represent the natural flow regime of a river, and they are the primary inputs to surface-water models currently being developed in the State. Current or projected water use can be superimposed on the UIFs to quantify water availability throughout a basin and to predict the location, duration, and frequency of possible water shortages. New water management strategies can also be tested with UIFs to determine which are most effective.

While there are more than 100 active USGS streamflow gages in the State, only a handful have been active for longer than 50 years. Synthetic hydrograph techniques can be used to extend short-record gages by using long-record gages as references. Evaluation of synthetic records through comparison with the original gaged records provides evidence that the extensions are representative of historic flows.

The purpose of this paper is to review methods used to produce extended UIFs for the South Carolina Surface Water Assessment (CDM Smith, 2015a). Extended UIFs will be used to 'seed' the Simplified Water Allocation Model currently under development for each major river basin in the State.

\section{SIMPLIFIED WATER ALLOCATION MODEL}

The Simplified Water Allocation Model (SWAM CDM Smith, 2016) was developed by CDM Smith in 2009 as a desktop tool to facilitate regional and statewide water allocation analysis (CDM Smith, 2015b). SWAM is programmed with Visual Basic for Applications and works in a Microsoft Excel spreadsheet. It is an object-oriented tool in which a river basin and its influences can be linked into a network with user-defined priorities.

SWAM provides an interactive and consistent platform for water availability and management studies in each of South Carolina's eight major river basins. It uses historic water data to address questions such as:

a) Will future management or withdrawals result in water shortages? How much, how often, and where?

b) Will future water uses be compatible with instream flow needs?

c) Can alternative management scenarios better utilize water resources in a basin?

This work represents the first step in the first phase of South Carolina's statewide planning initiative - the quantification of surface water in each of the state's major river basins. Following this phase, estimates of groundwater availability and water demand will be developed, and the information will be used for regional and statewide water plans.

\section{PROJECT DESCRIPTION}

The Saluda River basin is a long, narrow basin transecting the Blue Ridge and Piedmont physiographic provinces of South Carolina and extending southeast past the Fall Line in the central part of the State. The regulatory Saluda basin is the 4th largest in the State, encompassing an area of approximately 3,210 square miles, or 10.3 percent of the land area of the state.

The Saluda River is the major watercourse in the basin. This river has its headwaters in the Blue Ridge physiographic province of South Carolina, and flows southeasterly across the Piedmont before joining the Broad River to form the Congaree River near Columbia (the Congaree is considered a part of the Saluda regulatory basin). Major tributaries include the Reedy River, Rabon Creek, Little River, Bush River, and Little Saluda River. All reservoirs greater than $0.27 \mathrm{mi}^{2}$ within the study area are included in the study: Table Rock Reservoir, North Saluda Reservoir, Saluda Lake, Rabon Lake, Lake Greenwood, and Lake Murray. Other reservoirs in the study area, all smaller than $0.15 \mathrm{mi}^{2}$, were not included in this analysis. Streams and reservoirs were mapped using the National Hydrography Dataset produced by USGS.

The Saluda basin as discussed herein refers only to the portion of the regulatory Saluda basin upstream of the confluence with the Broad.

\section{METHODS}

\section{Calculation of UIFs}

Withdrawals, discharges, and reservoir operations are used to 'unimpair' gage data on a daily basis using the equation:

$$
U I F=Q+W-D+\Delta S_{r}+E_{r}-P_{r} \quad E q .1
$$

where UIF is unimpaired flow; $Q$ is measured gage flow; $W$ is total withdrawals from streams or reservoirs upstream of the gage; $D$ is total discharges to streams or reservoirs upstream of the gage; $\Delta S_{r}$ is change in upstream reservoir storage volume; $E_{r}$ is evaporation from reservoir surfaces; and $P_{r}$ is precipitation on reservoir surfaces. Where reservoirs with large surface areas exist upstream of streamflow gages, UIF calculations account for runoff that would have occurred on land that was submerged by reservoirs at the time of streamflow readings. Direct precipitation on the reservoir surface is adjusted by this estimate in Equation 1. All quantities are converted to cubic feet per second (cfs) for the UIF calculation.

Records from 28 USGS streamflow gages are used in this study (Table 1, Figures 2 and 3). Table 1 serves as a key to USGS site numbers, gage IDs used in this project, site names, and drainage areas. Each gage has a distinct period of record, the longest of which dates back to 1925 (Saluda River near Columbia; Figure 3). Many gages, however, began recording only in the 1980s and 1990s. Some gages have since been discontinued and others have gaps in their records. 


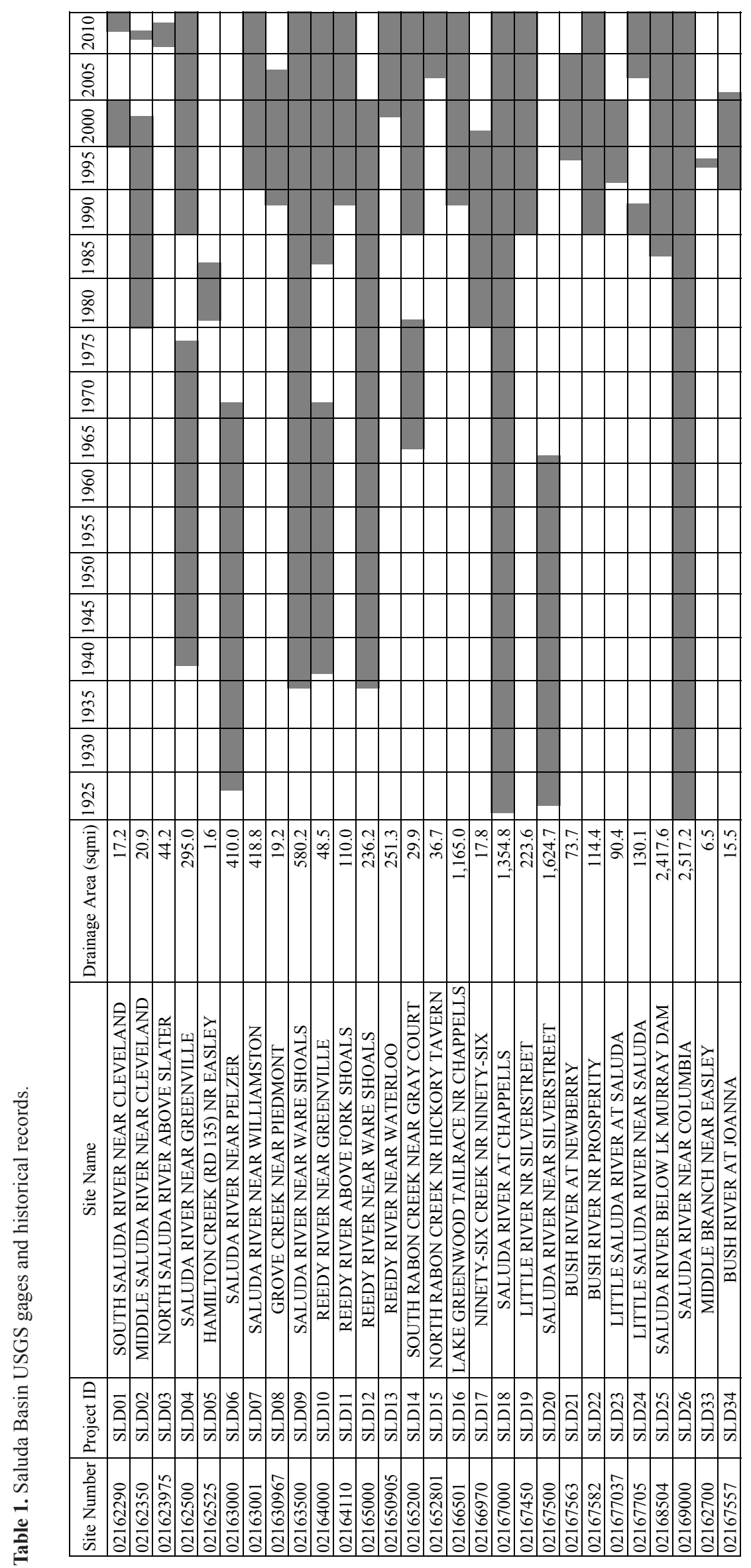




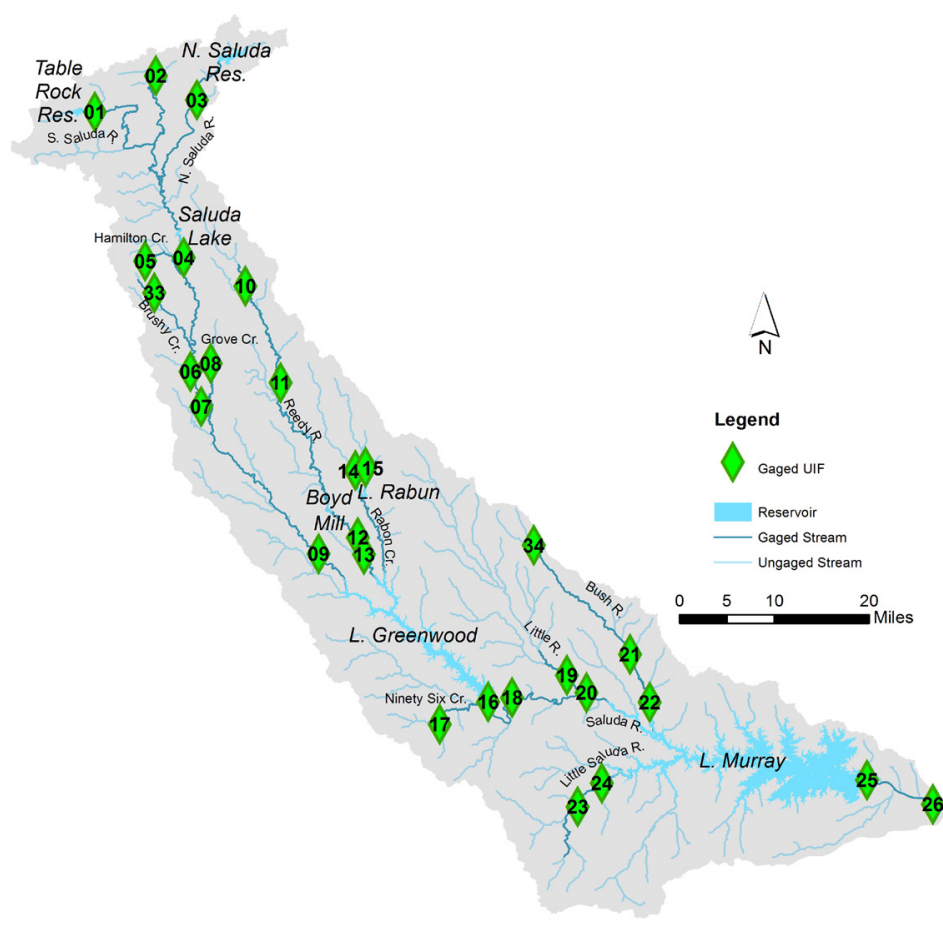

Figure 2. Map of study area - USGS stream gages are labeled with project ID numbers.
DHEC provided most of the data on current and former withdrawers and dischargers in the basin. Other water use and discharge data were collected from water utilities, individual users, or through anecdotal information. Withdrawals for municipal, industrial, agricultural, thermoelectric power generation, mining, and golf course irrigation are included in the study. In general, only withdrawals and discharges of 3 million gallons or more per month $(0.15 \mathrm{cfs})$ are used to unimpair flows. Reservoir operations and levels were obtained from dam operators, the Federal Energy Regulatory Commission (FERC) reports, and the USGS. Withdrawal and discharge data are collected by DHEC and are reported by water users on a monthly basis. There are reporting errors as well as additional uncertainty when interpolating to a daily time step. Intra-monthly water use has been assumed constant for the purposes of UIF development.

\section{Hindcasting Water Use and Operational Data}

Where water use and operational records were incomplete, it was necessary to estimate impairments. Withdrawals are hindcast using anecdotal information, regional population trends, or interpolation for short-term gaps. Where monthly fluctuations are evident, average monthly deviations from the annual mean in documented data were used to adjust the hindcast. Discharges are hindcast

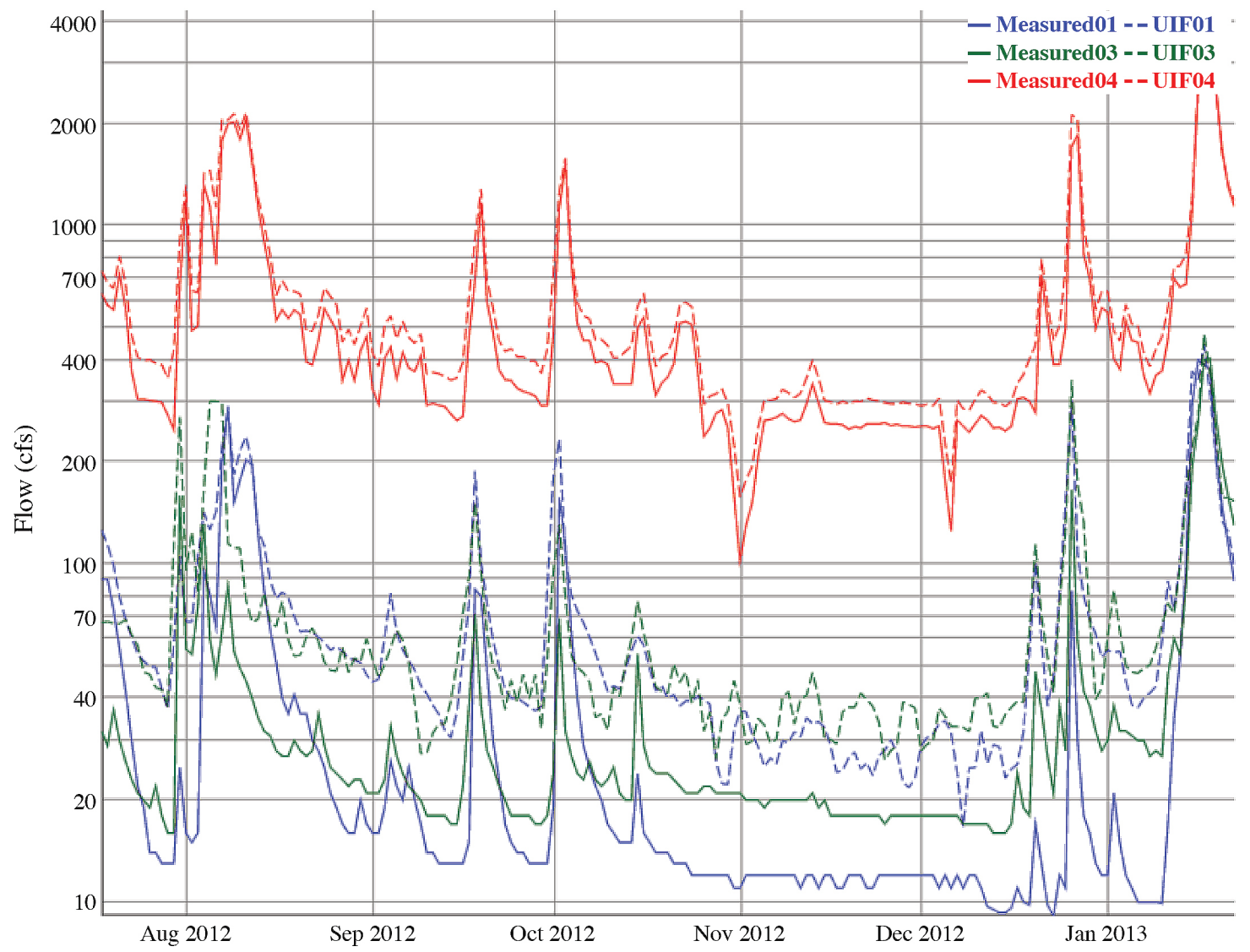

Figure 3. SLD01 and SLD03 are among the most impaired gages in the Saluda basin, as a percentage of streamflow. The impacts on SLD04, located downstream, are relatively smaller. 
similarly, and they may also be correlated with recorded withdrawal volumes, or based on data in the discharge permit. In the absence of records, reservoir hindcasts are based on observed patterns of drawdown related to prior rainfall. The methods are detailed in other documentation (CDM Smith, 2015c).

Withdrawal rates for agricultural irrigation were hindcast using the total irrigated acres per county (USDA NASS, 2012), recommended irrigation amounts (USDA NCRS, 2010), monthly rainfall (Menne et al., 2012a and 2012b), the irrigation volumes from surface water compared to ground water in the county and monthly adjustment factors based on withdrawals reported to DHEC. Hindcast estimates were then calibrated using reported withdrawals from 2002-2012. No irrigation was reported for South Carolina in the Census of Agriculture prior to 1950 and, consequently, agricultural hindcasts end at that point. This is consistent with historical accounts of the collapse of cotton and tobacco prices in the 1920s, followed by a series of droughts and infestations that greatly impacted South Carolina agriculture through the 1930s (Edgar, 1998).

\section{UIF Extensions}

UIF extensions are calculated using other UIFs as references. UIFs that correlate well with the short-record UIF during an overlapping period of record or with basin characteristics, are selected as candidate references for the extension of the short-record gage. In some cases, UIFs from adjacent basins are used in the extension process.

For each gage that needs extension, a list of candidate reference gages is selected based on the following criteria:

1) Daily correlation between the UIFs of the two gages

2) Upstream/downstream relationship of the two gages

3) Candidate reference gage data quality

4) Comparable drainage area size (generally, within a factor of 2 or 3 , if possible)

5) Relative amounts of land use, according to the National Land Cover Dataset (NLCD) (Homer et al., 2015)

6) Average slope of the basin as determined with the National Elevation Dataset (USGS, 2009)

7) Soil Conservation Service Runoff Curve Number, calculated using the NLCD (USDA, 1986)

Often, several reference gages are used to extend a given short-record gage. The criteria listed above are ordered by importance, but an extreme mismatch in any criteria indicates a poor reference gage candidate.

The principle method used for extension in this project is Maintenance of Variance Extension type 1 (MOVE.1 from Hirsh, 1982):

$$
\hat{y}(i)=m\left(y_{1}\right)+\frac{S\left(y_{1}\right)}{S\left(x_{1}\right)}\left(x(i)-m\left(x_{1}\right)\right) \quad \text { Eq.2 }
$$

where $\hat{y}(i)$ is the estimated flow at the short-record gage at the $i$ th time step; $m\left(y_{p}\right)$ is the mean of the measured flow at the short-record gage during the overlapping time period; $S\left(y_{p}\right)$ is the standard deviation of the measured flow at the short-record gage; $S\left(x_{p}\right)$ is the standard deviation of the long-record gage during the overlapping time period; $x(i)$ is the measured flow at the long-record gage on the $i$ th time step; and $m\left(x_{p}\right)$ is the mean of the long-record gage during the overlapping time period. Generally, flow data are not normally distributed and therefore are transformed using $\log$ base 10 before determining the mean and standard deviation and applying Equation 2. The antilog of the output is the estimated flow in the same units as the input flow data.

The MOVE. 1 technique was employed in the update of the Oklahoma Comprehensive Water Plan (OCWP) in 2012 to help extend streamflow records throughout the state (Oklahoma Water Resource Board, 2012).

The MOVE. 1 method requires an overlapping period of record. In some cases, a candidate reference gage may not have an overlapping record with the short-record gage but may be a strong candidate on the basis of drainage area, slope, and land use. Even without an overlapping period of record, the ratio of daily streamflow to drainage area at a candidate reference gage can be used to extend a shortrecord gage. This is referred to here as area ratio.

A variation on MOVE.1, using untransformed data, was also tested in this project. Negative or unrealistically low flows often can result from applying MOVE.1 on untransformed flow data. A hybrid approach is used with values from area ratio substituting for output values below a certain threshold. This threshold is determined by the minimum flow at the short-record gage during the overlapping period of record.

\section{RESULTS}

Results of the un-impairment process show that the largest differences between gaged and unimpaired stream flows were caused by reservoir operations. Figure 3 shows substantial impairments occurred at gages SLD01 and SLD03, caused by Table Rock Reservoir and North Saluda Reservoir, respectively. These impairments are substantial relative to the flow in those headwater streams, but they represent a smaller percentage of the total flow downstream at SLD04.

Impairments on the Reedy River are notable because the UIF is often less than the gaged flow. This is caused by significant discharges from a wastewater treatment plant upstream. Another notable impairment on the Reedy River is caused by historical operations at Boyd Mill Pond. No observed reservoir data were available for Boyd Mill Pond, but reservoir operations left a distinct signal in the gaged hydrographs downstream (Figure 4). Apparently, streamflow was retained in the pond on Sundays during certain periods, while during other periods such pronounced streamflow detention is not apparent in the gage record. Without accurate 
Pellett, Boyer, Caraway, Cox, Gellici, Harder, Wachob, Westphal

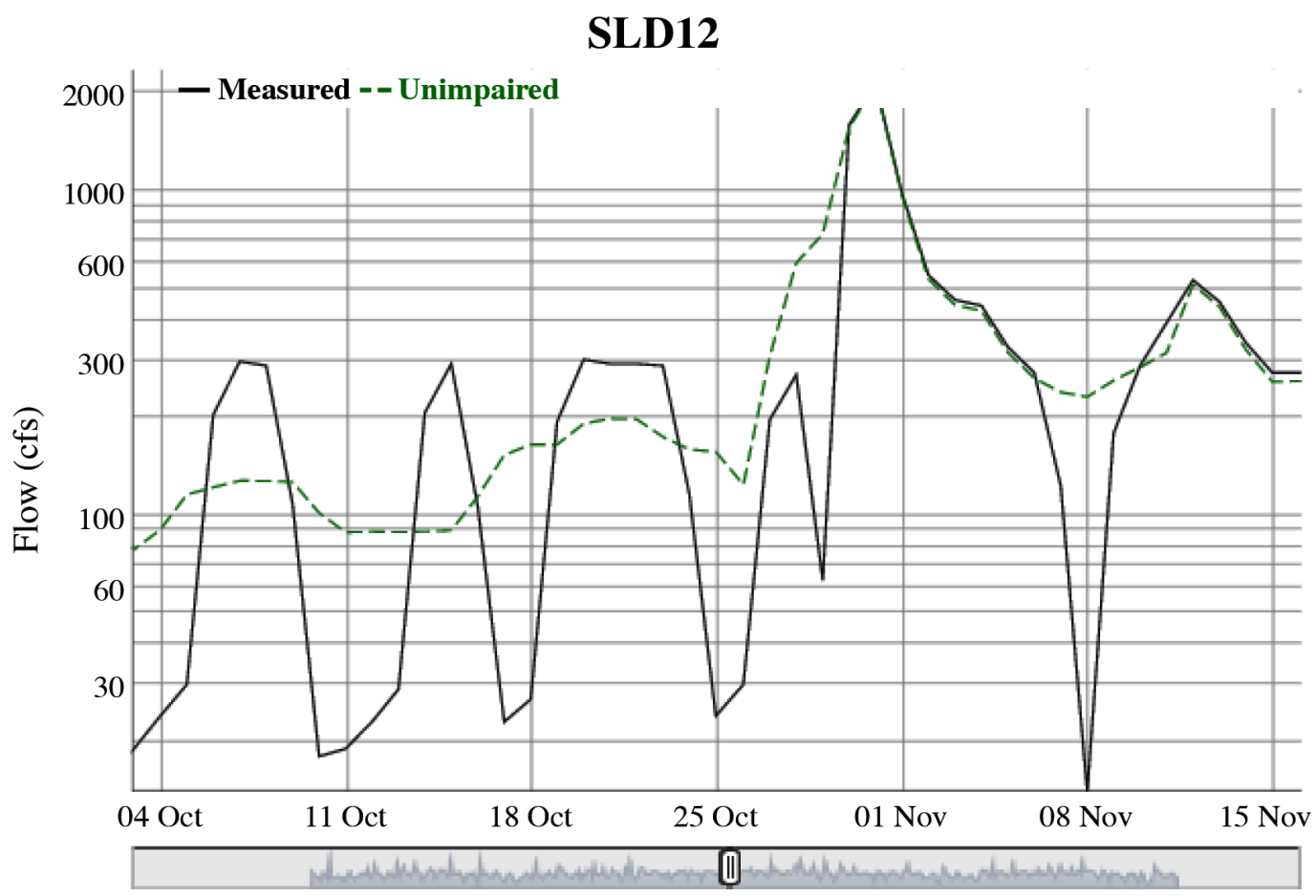

Figure 4. Unrecorded operations at Boyd Mill Pond impaired streamflow at SLD12, 1970.

records of reservoir operations, it is unclear whether the gage data can be reliably unimpaired on a daily time step. In this case, a 7-day moving average is used to smooth the gaged flow during the periods when reservoir operations are evident.

No impairments were found for SLD02, SLD05, SLD08, SLD14, SLD15, SLD17, or SLD34. SLD24 was significantly affected by backwater from Lake Murray and was deemed unsuitable for UIF development.

Table 2 shows the reference gages and extension methods chosen for each short-record gage as a result of this work. The extension of most short-record gages requires several reference gages to cover different periods of time. Every short-record gage extension relies on SLD26, because SLD26 is the longest running gage in the basin.

Figure 5 is used to verify the ability of the extension reference gages and methods to reproduce flows at SLD03. The verification plot shows only the overlapping period of record. Figures 6 and 7 show the extension results for SLD01, SLD03 (Figure 6), SLD09, SLD22, SLD23 (Figure 7).

SLD03 is a particularly difficult extension, not only because of the significant impairments on SLD03, but also because of its relatively brief period of record. Note that the different parts of the UIF extension show distinct streamflow dynamics. This is especially apparent in the cases of SLD03 and SLD23. While some variability in streamflow dynamics is natural and expected due to variable precipitation, it appears that the distinct reference gages and extension techniques can introduce additional variability in the streamflow patterns.

\section{DISCUSSION}

In the Saluda basin, reservoirs cause the most substantial impairments of streamflow. This indicates that accurate reservoir modeling is important for modeling flows in the basin as a whole.

Generally, area ratio was the poorest extension technique, and MOVE.1 outperformed the other techniques in most cases. Using a hybrid technique to minimize deficiencies in the untransformed MOVE.1 method led to improved results. This supports the idea that distinct methods which each best represent different aspects of streamflow may be combined to improve overall results. However, it is possible that such methods may 'overfit' the validation dataset, appearing to provide good results without actually representing physical processes adequately.

While MOVE. 1 is supported both in practice and in theory, it has been outperformed by several variations including MOVE.2 and MOVE.3 (Hirsch, 1982, Vogel and Stedinger, 1985). For the purposes of this work, the authors determined that the possible improvements were offset by the computational complexity of these variations. A number of other hydrograph extension techniques have been developed, each with advantages and disadvantages that should be considered in light of the specific application (see Moog et al., 1999, for example).

It is important to note the uncertainty in the early years of the extended period of record. With only a single candidate reference gage, it is not possible to represent the range of short-record gages as accurately as might be desired using the methods described here. 
Table 2. Selected reference gages and extension methods for short-record gages.

\begin{tabular}{|c|c|c|c|c|c|}
\hline $\begin{array}{c}\text { Short-record } \\
\text { gage }\end{array}$ & $\begin{array}{c}\text { Reference } \\
\text { Gage }\end{array}$ & $\begin{array}{c}\text { Extension } \\
\text { Method }\end{array}$ & $\begin{array}{c}\text { Short-record } \\
\text { gage }\end{array}$ & $\begin{array}{c}\text { Reference } \\
\text { Gage }\end{array}$ & $\begin{array}{c}\text { Extension } \\
\text { Method }\end{array}$ \\
\hline 01 & 02 & MOVE.1 & 10 & 14 & Hybrid \\
\hline 01 & 04 & MOVE.1 & 10 & 18 & Hybrid \\
\hline 01 & 18 & MOVE.1 & 10 & 26 & MOVE.1 \\
\hline 01 & 26 & MOVE.1 & 11 & 10 & MOVE.1 \\
\hline 02 & 01 & Hybrid & 11 & 18 & MOVE.1 \\
\hline 02 & 04 & MOVE.1 & 11 & 26 & MOVE.1 \\
\hline 02 & 18 & Hybrid & 12 & 13 & Area Ratio \\
\hline 02 & 26 & Hybrid & 12 & 18 & Area Ratio \\
\hline 03 & 02 & Hybrid & 12 & 26 & Area Ratio \\
\hline 03 & BRD11* & MOVE.1 & 13 & 18 & Hybrid \\
\hline 03 & 04 & Hybrid & 13 & 26 & Area Ratio \\
\hline 03 & 18 & Hybrid & 14 & 10 & MOVE.1 \\
\hline 03 & 26 & Hybrid & 14 & 18 & MOVE.1 \\
\hline 04 & 06 & MOVE.1 & 14 & 26 & MOVE.1 \\
\hline 04 & 09 & MOVE.1 & 15 & 14 & Area Ratio \\
\hline 04 & 18 & MOVE.1 & 15 & 18 & Hybrid \\
\hline 04 & 26 & MOVE.1 & 15 & 26 & Hybrid \\
\hline 05 & 18 & MOVE.1 & 16 & 18 & MOVE.1 \\
\hline 05 & 26 & MOVE.1 & 16 & 26 & Hybrid \\
\hline 06 & 04 & MOVE.1 & 17 & 22 & MOVE.1 \\
\hline 06 & 09 & MOVE.1 & 17 & 18 & MOVE.1 \\
\hline 06 & 18 & MOVE.1 & 17 & 26 & MOVE.1 \\
\hline 06 & 26 & MOVE.1 & 18 & 26 & Hybrid \\
\hline 07 & 09 & Hybrid & 19 & 18 & Hybrid \\
\hline 07 & 18 & MOVE.1 & 19 & 26 & Hybrid \\
\hline 07 & 26 & MOVE.1 & 20 & 18 & MOVE.1 \\
\hline 08 & 11 & Hybrid & 20 & 26 & Area Ratio \\
\hline 08 & 10 & Hybrid & 21 & 22 & MOVE.1 \\
\hline 08 & 14 & MOVE.1 & 21 & 26 & MOVE.1 \\
\hline 08 & 18 & MOVE.1 & 22 & 26 & MOVE.1 \\
\hline 08 & 26 & MOVE.1 & 23 & 17 & Area Ratio \\
\hline 09 & 06 & MOVE.1 & 23 & 22 & Area Ratio \\
\hline 09 & 18 & MOVE.1 & 23 & 18 & Area Ratio \\
\hline 09 & 26 & MOVE.1 & 23 & 26 & Area Ratio \\
\hline 10 & 06 & MOVE.1 & 25 & 26 & Hybrid \\
\hline
\end{tabular}

* Refers to USGS gage number 2154790 on the South Pacolet River

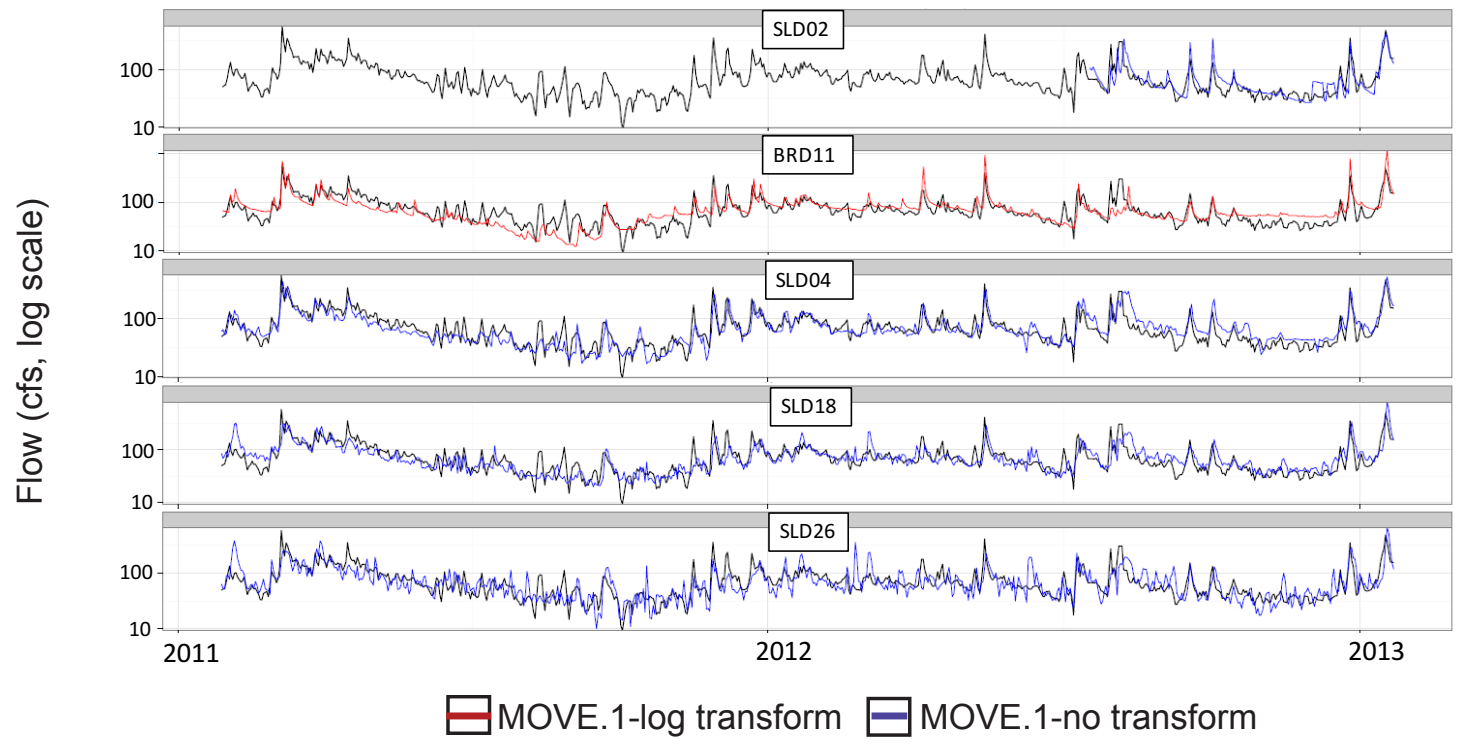

Figure 5. Verification of extension methods and reference gages for SLD03 is done by comparison of SLD03 UIF (black line) with extension outputs. 


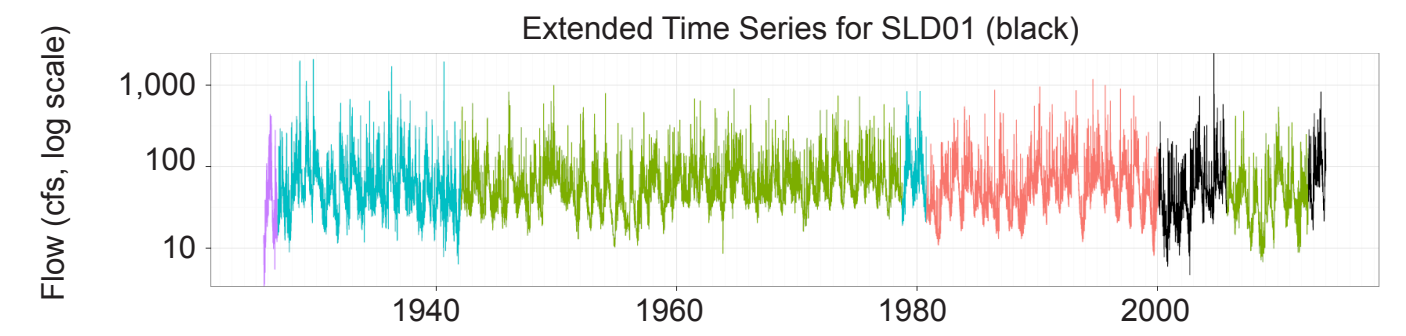

SLD02 (MOVE.1-log transform) - SLD04 (MOVE.1-log transform) $\square$ SLD18(MOVE.1-log transform) $\square$ SLD26 (MOVE.1-log transform)

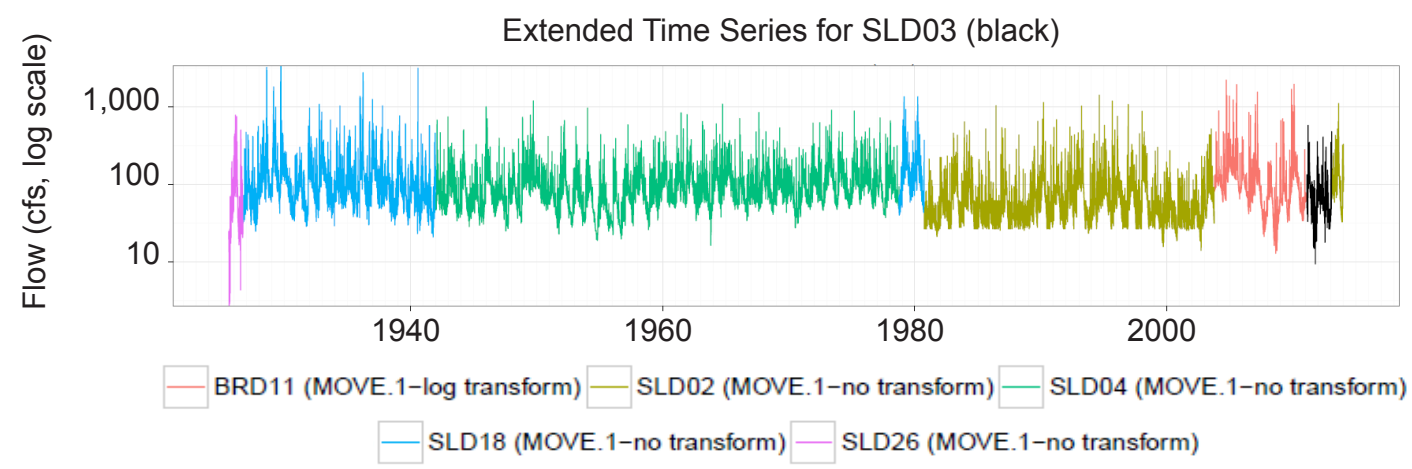

Figure 6. Extended UIFs for SLD01 and SLD03 - colors represent distinct reference gages and extension methods.

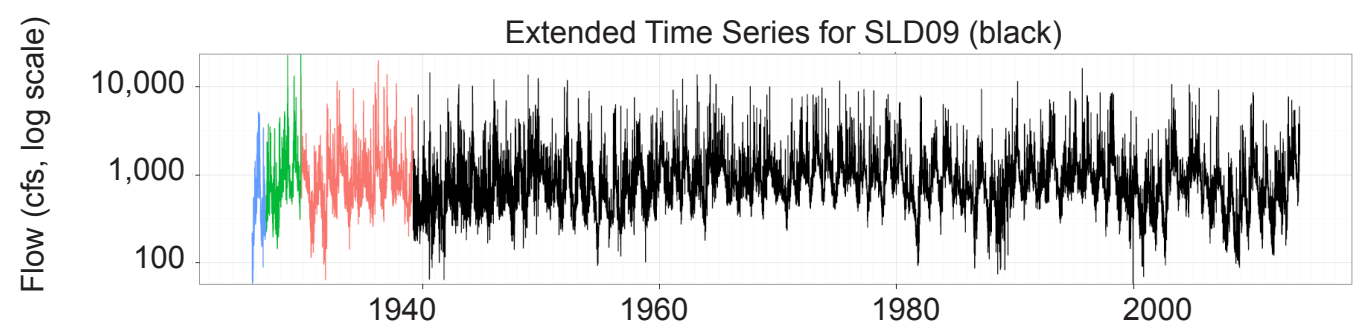

— SLD06 (MOVE.1-log transform) — SLD18 (MOVE.1-log transform) — SLD26 (MOVE.1-log transform)
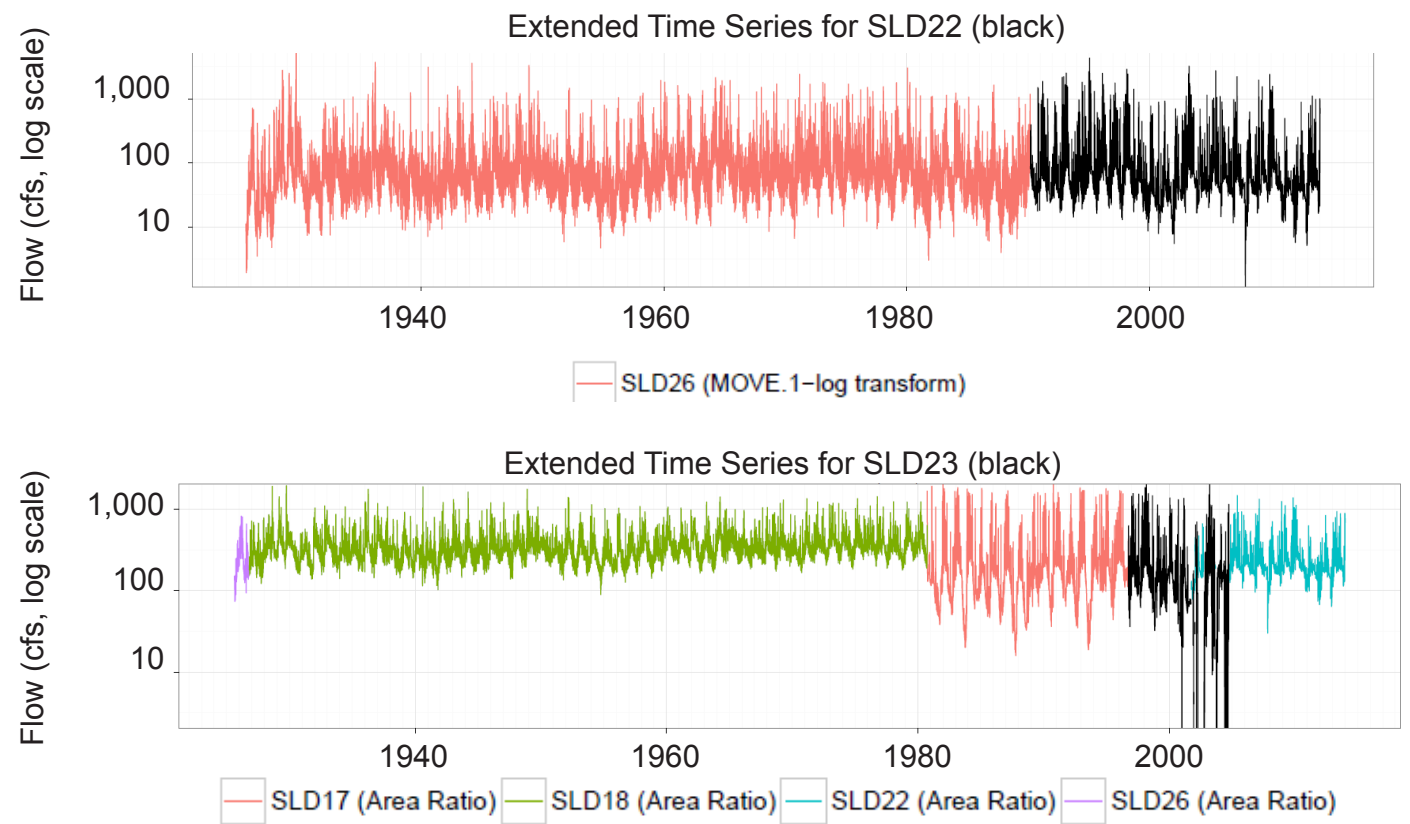

Figure 7. Extended UIFs for SLD09, SLD22, and SLD23 - colors represent distinct reference gages and extension methods. 
Uncertainty in any of the parameters used in UIF calculation causes uncertainty in the UIF, including gage data. USGS stream gage data is quality-controlled, and rated categorically from excellent to poor. These quality ratings correspond to $95 \%$ confidence intervals of $+/-5 \%$ for excellent to $>15 \%$ for poor (USGS, 2015).

While it is not within the scope of this paper to fully detail the exact calculations used to unimpair and extend each gage in the basin, we hope to communicate the general process and results. Further information is available online, at the sites listed in the text above and in the bibliography below. Any questions or recommendations for improving the UIFs can be directed to the primary author.

\section{ACKNOWLEDGMENTS}

Documentation of methods and results provided by CDM Smith formed the basis for this work. Methods were revised based on collaborative discussion once the work began. First author is merely the messenger, all other authors are listed in alphabetical order.

\section{LITERATURE CITED}

CDM Smith, 2015a, Unimpaired Flow Dataset of the Saluda River Basin. October 2015.

CDM Smith, 2015b, SWAM User's Manual 3.0. October 2015. CDM Smith, 2015c. Guidelines for Standardizing and Simplifying Operational Record Extension. March 2015.

Edgar, Walter B. South Carolina: A History. Columbia: University of South Carolina Press, 1998.

Hirsch, R.M., 1982. A Comparison of Four Streamflow Record Extension Techniques. Water Resources Research 18: 1081-1088.

Homer, C.G., Dewitz, J.A., Yang, L., Jin, S., Danielson, P., Xian, G., Coulston, J., Herold, N.D., Wickham, J.D., and Megown, K., 2015, Completion of the 2011 National Land Cover Database for the conterminous United StatesRepresenting a decade of land cover change information. Photogrammetric Engineering and Remote Sensing, v. 81 , no. 5 , p. 345-354.

Menne, Matthew J., Imke Durre, Bryant Korzeniewski, Shelley McNeal, Kristy Thomas, Xungang Yin, Steven Anthony, Ron Ray, Russell S. Vose, Byron E.Gleason, and Tamara G. Houston, 2012a: Global Historical Climatology Network - Daily (GHCN-Daily), Version 3. NOAA National Climatic Data Center. doi:10.7289/V5D21VHZ [4/2015].

Menne, Matthew J., Imke Durre, Russell S. Vose, Byron E. Gleason, and Tamara G. Houston, 2012b: An Overview of the Global Historical Climatology Network-Daily Database. J. Atmos. Oceanic Technol., 29, 897-910. doi:10.1175/JTECH-D-11-00103.1.
Moog, Douglas B., Peter Whiting, and Robert Thomas, 1999. Streamflow record extension using power transformations and application to sediment transport. Water Resources Research, v. 35, no. 1, p. 243-254.

Oklahoma Water Resources Board, 2012. http://www.owrb. ok.gov/supply/ocwp/ocwp.php Accessed 8/1/2016.

SCDNR, 2016. Surface Water Modeling and Assessments. http://www.dnr.sc.gov/water/waterplan/surfacewater.html Accessed 3/21/2016.

United States Department of Agriculture (USDA), 1986. Urban Hydrology for Small Watershed. Technical Release 55 (TR-55) (Second ed.). Natural Resources Conservation Service, Conservation Engineering Division.

USDA NASS, 2012. Census of Agriculture. www.agcensus. usda.gov/Publications/2012/Online_Resources/Ag Census_Web_Maps/Overview Accessed 3/21/2016

USDA NCRS, 2010. North Carolina Irrigation Guide. http://www.bae.ncsu.edu/topic/irrigation_society/info/

NC_Irrigation_Guide_Apr_2010.pdf Accessed 3/21/2016

USGS, 2009. National Elevation Dataset. http:// nationalmap.gov Accessed 3/21/2016

a Report Documentation. http://wdr.water.usgs.gov/current/ documentation.html. Accessed 3/15/2016.

Vogel, R.M., and J.R. Stedinger, 1985. Minimum variance streamflow record augmentation procedures, Water Resources Research, v. 21, p. 715-723. 